\title{
Analysis Factors of Modernization Policy on Tanjung Emas Port Semarang
}

\author{
Edy Mulyanto ${ }^{1}$, Indah Susilowati ${ }^{2}$, Hardi Warsono ${ }^{3}$, Retno Sunu ${ }^{4}$ \\ \{indahsusilowati@undip.ac.id ${ }^{2}$ \} \\ Universitas Diponegoro, Indonesia ${ }^{1,2,3,4}$
}

\begin{abstract}
The port as the gateway to trading activities is one of the defining elements of economic enhancement. Therefore, the port must be managed properly, effectively and efficiently to be able to encourage the industrial activities in an area so that the economic progress achieved by the community. However, until now it is still facing many problems that occur in some ports, especially in Tanjung Emas port Semarang. The problem is that the administration process takes a long time, causing the dwelling time in removing containers from the port. This study applies the theory from by Grindle. The research method is qualitative, using purposive sampling, with triangulation techniques. The results show that the supporting factor is the implementation context which is the magnitude of the power, interests, and strategies owned by the actors involved, characteristics of the current institution and regime. The level of compliance and responsiveness of target groups are always in compliance with existing policy regulations. Although the policy regulation used today is the content of policy of Act No. 17 in 2008 about sailing being an inhibitory factor in this research. The recommendation provided by the researcher is to make changes to Law No. 17 in 2008 concerning shipping, particularly in chapters 79 , and paragraphs two.
\end{abstract}

Keywords: Content of Policy, Context of Implementation, Port Modernization.

\section{Introduction}

Indonesia is an archipelago that requires many ports to support economic activities, whether the main port, the feeder port and the collecting port.

In regulating a port, the government issued Act Number 17 in 2008 about shipping. It is stating, "Port is a place consisting of land as well as water with certain boundaries as a place of government activities and used as a place of the ship for leaning, boarding and loading as well as unloading goods. In the form of a terminal and ship berth equipped with safety and security facilities of sailing and port supporting activities as well as a place of intra displacement and inter-mode transportation".

With the enactment of Act Number 17 in 2008 concerning sailing does not necessarily make the port free of problems, the main problem that many found in some ports is no exception Tanjung Emas port is dwelling time. In addition, based on the Ministry of Finance data in 2016, Tanjung Emas Port is the port that has the oldest time in the settlement of customs documents that caused the dwelling time compared to Tanjung Priok, Belawan and Tanjung Perak Ports. 
Fig. 1. Indicators of Average Major Performance at Completion Time Process of Customs Documents

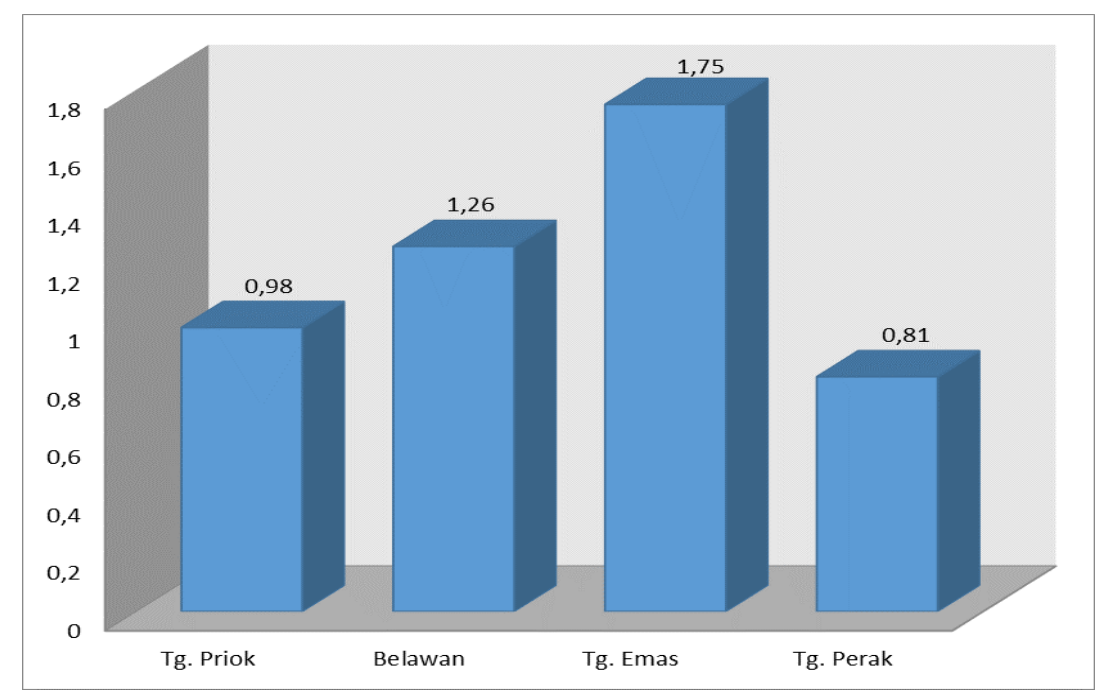

Source: Performance Report of Ministry of Finance of Indonesia Republic, 2016.

The Researchers feel interesting because of the weak of Act Number 17 in 2008 currently suspect the period of the Dwelling time that occurred in Tanjung Emas Port Semarang. This makes the authors interested in conducting research by taking the title of analysis of Analysis Factors of Modernization Policy on Tanjung Emas Port Semarang.

\section{Methodology}

This research uses a qualitative approach. Moloeng [1] to find out the methods and strategies applied in the quality of the public services and the constraints and efforts faced. The data source obtained is primary data and secondary data. Primary Data obtained through an in-depth interview source, Focus Group Discussion, and observation. Secondary Data obtained through literature and documentation studies. The analysis Unit in this research is the government as the manager of the port (KSOP), business entity (Pelindo), community, and the industry people in the port and the community that many utilize the service facilities in Tanjung Emas Port.

Sampling techniques performed in purposive sampling. The data collection techniques used is as follows: documentation, observation, and interviews. Qualitative data analysis techniques are through. (1) Data reduction (2) Display or Data presentation (3) Data verification [2]. Using the validity and validity test of data using the source triangulation technique, which based on many data sources in the form of interviews, data and facts in the field? 


\section{Result and Discussion}

\subsection{Content of Policy as a Policy Inhibitory Factor in Tanjung Emas Port}

According to the research results that have been done, it is known that the Variable content of policy is the Act Number 17 in 2008 about sailing is a factor in the port management. [3] mentioned that in the variable Content of Policy contains several indicators that include the interests of target groups contained in policy regulations, the type of benefits received by the target groups, the desired change from a policy, the accuracy program, mentioning its implementation in detail, and supported by adequate resources.

From the research, results can be noted that some of the articles contained in Act 17 in 2008 on article 79. It stated about activities of government and administration in the port is held in an integrated and coordinated and in paragraph 2 about government activities in the Port Authority in a direct does not control that so that the activities at the port cannot be control by the Port Authority. The public service has not been good, effective and efficient to the service users in that port so that the impact of such is the dwelling time as depicted in the chart 3.1. Another result is the policy in the port that does not involve the Port authority so it is detrimental and burden the operational costs of the perpetrators in the port industry, supply chain and logistic.

Fig. 2. Dwelling Time Occurring In Tanjung Emas Port Semarang

Outline of port facilities and procedures for entering and leaving

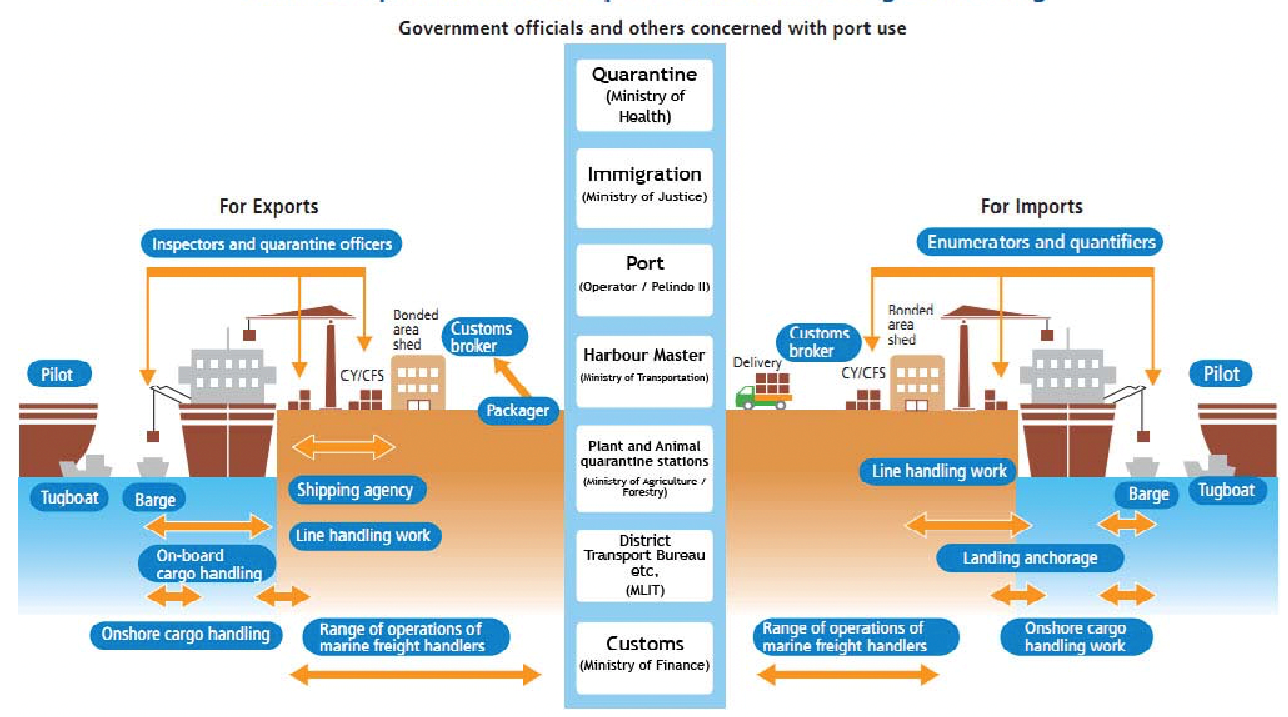

Source: Tanjung Emas Official, 2016.

Based on the figure 2, you can observe that the average dwelling time in Tanjung Emas Port Semarang is still quite old. The absence of conformity between the theory used, regulations issued by the Government, and the practice in the field thus making the port management program to reduce the waiting time and the convoluted document management makes. The cruise Act has not been maximized. Because the indicators presented by [3] were 
the types of benefits received by the target groups, the desired changes of a policy, the program accuracy, the implementation of policies, and supported by adequate resources in the rules Still do not accommodate if implemented in all ports locate in Indonesia.

\subsection{Context of Implementation (Environmental Policy) as a Policy Supporting Factor in Tanjung Emas Port Semarang}

The research results have been done previously, can be known that the supporting factor in this study is a Variable environmental policy implementation (Context of Implementation) where the actors or stakeholders involved A lot of activity in the harbor. Grindle mentioned that in the environment variable implementation policy (Context of Implementation) contains several indicators that include the magnitude of power, interests, and strategies owned by the actors involved, characteristics Governing institutions and regimes, the level of compliance and the responsiveness of target groups.

Fig. 3 Port Activities Graph

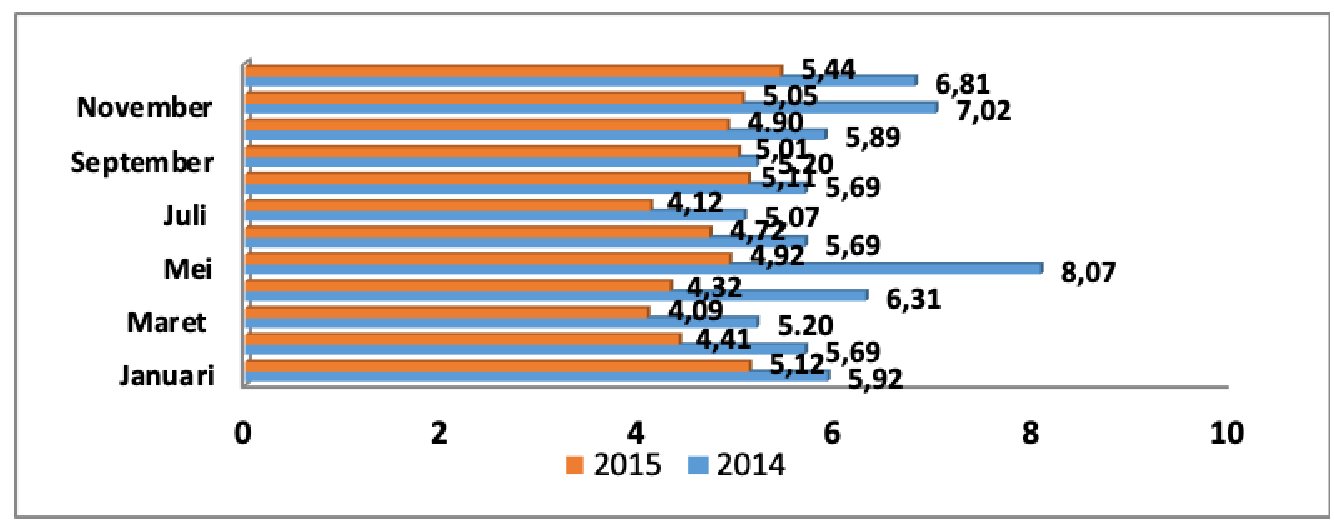

Source: National Centre Port, 2016.

According to the Figure 3, you can observe the management process of the port in a plot from the ship to the loading and unloading process as well as document management. However, occurring in the field is still constrained by the rules and policies that apply, so that the condition does not make the responsiveness of actors and stakeholders involved in the port management and cause amount of loss to the perpetrators Business at the port.

There is conformity between the theories used by researchers, with practice in field; it does not cause many problems when [3][4][5] theory associated with a variable context of implementation that is used to explore Problem of policy in modernization management in Tanjung Emas Port Semarang. This is because of the strong support of the power indicator, the importance, and the strategy of the actors involved are always obedient and obedient to the prevailing rules, thereby making the level of compliance and responsiveness of society or Stakeholders who conduct a lot of their activities in the port remain high without disapproving of current rules. 


\section{Conclusion}

The implementation of Act Number 17 in 2008 about the sailing activity still poses problems caused by several agencies in the port in carrying out its functions using different legislation and Standard Operating Procedures. This is the obstacle of the implementation of the port modernization policy in Indonesia, especially in Tanjung Emas Port. Therefore, with these conditions researchers suggest that the revised policy on the sailing Act by revising some articles. The chapters are to return the role of the Port Authority as the highest authority in port management, and institutional reform at the port so that there is no chance of authority to achieve better service, effectively and efficiently by streamlining document management time limits.

\section{References}

[1] L. J. Moleong, "Metodologi Penelitian Kualitatif (Edisi Revisi)," in PT. Remaja Rosda Karya, 2017.

[2] M. B. Miles, A. M. Huberman, and J. Saldaña, "Qualitative data analysis: A methods sourcebook. 3rd," ed Thousand Oaks, CA Sage, 2014.

[3] M. S. Grindle, "Good Enough Governance,” Dev. Policy Rev., 2011.

[4] S. Abdul Wahab, "Analisis Kebijaksanaan Negara. Dari Formulasi ke Implementasi Kebijakan Negara." Edisi Kedua. Bumi Aksara. Jakarta, 2004.

[5] P. Sabatier and D. Mazmanian, "The implementation of public policy: A framework of analysis," Policy Stud. J., vol. 8, no. 4, pp. 538-560, 1980. 